7. Осборн Д., Пластрик П. Управление без бюрократов: пять стратегий об-новления государства. М., 2001.

8. Osborne D., Gaebler T. Reinventing Government: How the Entrepreneurial Spirit Is Transforming the Public Sector. N.Y., 1993.

9. Graham G., Amos B., Plumptre T. Principles Good Governance in 21-st Century // Policy Brief. 2003. № 15.

10. Dunleavy P., Margetts H., Bastow S., Tinkler J. New Public Management is Dead - Long Live-Digital Era Governance // Journal of Public Research and Administration Theory. 2006. Vol. 16, № 3.

11. К проблеме развития спонсорской деятельности в спорте // Луцкая А.В., Савельева О.В. // Тенденции развития науки и образования. 2020. № 67-4. С. 130-133.

\title{
Сагдакова А.Д. \\ Анализ изменений в бухгалтерском учете материально-производственных запасов в связи с переходом на новый стандарт
}

Адыгейский государственный университет

(Россия, Майкоп)

doi: $10.18411 / l j-02-2021-227$

idsp: ljournal-02-2021-227

Научный руководитель

Дивина Л.Э.

\section{Аннотация}

Статья посвящена анализу изменений в системе законодательного регулирования бухгалтерского учета материально-производственных запасов, вступающих в силу с 1 января 2021 года. В частности, проанализировано содержание ФСБУ 5/2019 «Запасы», проведен сравнительный анализ вводимого федерального стандарта с утрачивающими силу документами, которые регулируют учет материально-производственных запасов.

Ключевые слова: бухгалтерский учет, материалы, материальнопроизводственные запасы, федеральные стандарты бухгалтерского учета, международные стандарты бухгалтерского учета.

\section{Abstract}

The article is devoted to the analysis of changes in the system of legislative regulation of accounting of inventories, which come into force on January 1, 2021.In particular, the content of FSBU 5/2019 "Inventories" has been analyzed, a comparative analysis of the introduced federal standard with expiring documents regulating the accounting of inventories is carried out.

Keywords: accounting, materials, inventories, federal accounting standards, international accounting standards.

Одним из ключевых моментов реформирования российской системы бухгалтерского учета является ее адаптация к учетным системам развитых западных государств, которые базируются на международных стандартах финансовой отчетности. МСФО устанавливают единые принципы формирования отчетных показателей и предлагают варианты учета отдельных фактов хозяйственной деятельности в организациях. В настоящее время Министерство финансов РФ продолжает проводить активную политику по реформированию российских стандартов бухгалтерского учета и их сближению с международными стандартами финансовой отчетности. Тема введения МСФО в российскую учетную практику переходит из стадии многолетнего обсуждения в стадию практического внедрения. На смену старым нормативным документам пришел новый, более актуальный, федеральный стандарт ФСБУ 5/2019 «Запасы», разработанный на основе МСФО (IAS) 2 «Запасы» [1]. 
Это стандарт, который будет обязателен к применению раньше, чем все остальные разработанные российские федеральные стандарты - уже с 2021 года. Он дает большую возможность организациям оптимально наладить алгоритм учета материальных запасов. Стандарт обязателен к применению организациями, начиная с отчетности за 2021 год (в том числе промежуточной), при этом разрешается досрочное применение данного стандарта в добровольном порядке уже к отчетности за 2020 год. Проведем анализ изменений в учете МПЗ в связи с переходом на новый стандарт. Новый порядок учета значительно отличается от существующего. На рисунке 1 представлены нововведения, привнесенные новым стандартом ФСБУ 5/2019 в порядок учета материально-производственных запасов.

1. В стандарте впервые сформулировано и введено в научно-практический оборот понятие «запасы», что имеет большую практическую ценность. Так, согласно ФСБУ 5/2019, запасы - это активы, потребляемые или продаваемые в рамках обычного операционного цикла организации, либо используемые в течение периода не более 12 месяцев [3].

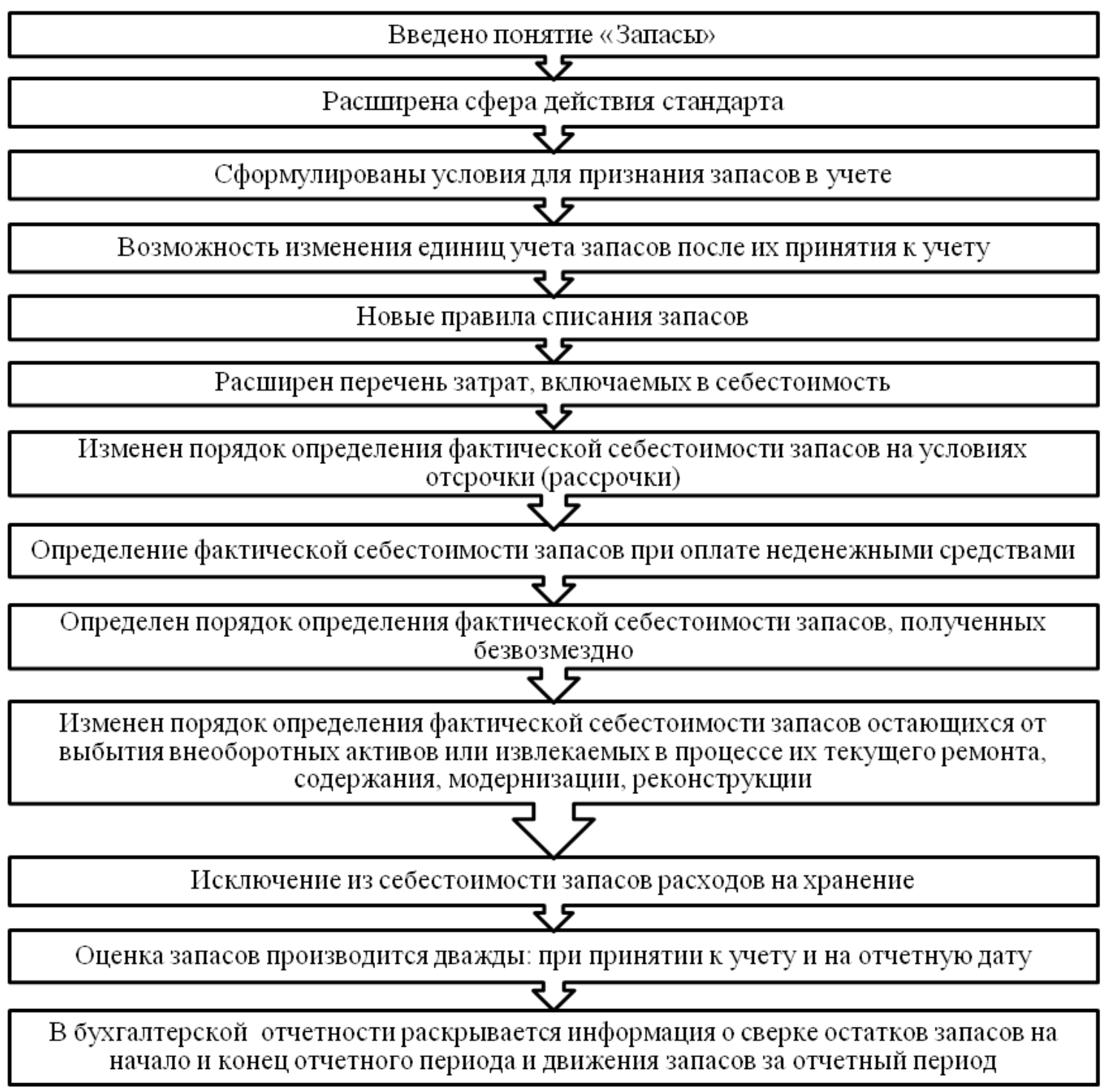

Рисунок 1. Изменения в учете материально-производственных запасов, вводимые ФСБУ 5/2019 «3anacbl»

2. Расширена сфера распространения стандарта - теперь стандарт предусматривает, что к запасам помимо сырья, материалов, товаров, готовой продукции, относится ещё и незавершенное производство, а также недвижимость и 
объекты интеллектуальной собственности, которые приобретались или создавались с целью продажи. Таким образом, организациям потребуется скорректировать систему калькулирования производственной себестоимости.

3. Согласно пункту 5 ФСБУ 5/2019 для признания запасов в учете должны выполняться два критерия одновременно, которые ранее не формулировались в ПБУ 5/01:

- для коммерческой организации затраты, возникшие в связи с приобретением или созданием запасов должны в дальнейшем принести ей экономическую выгоду;

- сумма затрат на приобретение или создание запасов (или приравненная к ней величина) должна быть определена.

4. С 2021 года у организаций появится законное право изменять единиць учета запасов. Как в ПБУ 5/01, так и в новом ФСБУ 5/2019 сказано, что организации вольны сами выбирать единицы учета запасов. Нововведение состоит в том, что допускаются последующие изменения единиц учета запасов, после того как они были признаны в бухгалтерском учете.

5. Новые правила списания запасов. Запасы теперь следует списывать не только в случае признания выручки от их реализации или иного выбытия, но также при выявлении факторов, в связи с которыми компания не ожидает в перспективе экономических выгод от потребления (продажи, использования) запасов, то есть, если стало известно, что запасы больше не соответствуют критериям актива. По ПБУ 5/01 запасы списывались только при выбытии [4].

6. Расширен перечень затрат, входящчих в фактическую себестоимость запасов. Фактическая стоимость запасов, помимо известных ранее составляющих, согласно ФСБУ 5/2019 включает в себя также:

- величину оценочного обязательства по демонтажу, утилизации и восстановлению окружающей среды, образовавшегося в связи с приобретением (созданием) запасов. Поэтому предприятиям потребуется долгосрочно прогнозировать последствия приобретения (создания) запасов;

- проценты, связанные с приобретением (созданием) запасов, в случае если запасы являются инвестиционным активом. Ранее подобные затраты относились на расходы текущего периода.

7. Изменен порядок определения фактической себестоимости запасов на условиях отсрочки (рассрочки) на период более 12 месяцев (или меньший срок, прописанный в учетной политике организации). Прежний подход предполагал учет запасов исключительно по номинальной стоимости. Новый подход более близок к финансовому менеджменту, так как с 2021 г. будет учитываться влияние времени при расчете стоимости запасов, приобретенных на условиях рассрочки (отсрочки): организации должны определять фактическую себестоимость таких запасов не по номинальной стоимости, а в размере дисконтированной стоимости будущих денежных потоков. Процент дисконтирования организация определяет самостоятельно и закрепляет в своей учетной политике. В данном случае организации должны руководствоваться правилами ПБУ 15/2008 «Учет расходов по займам и кредитам» [5].

8. Определение фактической себестоимости запасов при неденежном обмене. Запасы, приобретаемые от поставщиков по договорам, предусматривающим оплату неденежными средствами (полностью или частично), оцениваются по справедливой стоимости передаваемого имущества, имущественный прав, работ, услуг. Для расчета справедливой стоимости следует воспользоваться правилами, изложенными в МСФО (IFRS) 13 «Оценка справедливой стоимости». Только в случае 
обоснованной невозможности определения справедливой стоимости допускается использование балансовой стоимости [2].

9. Ранее, согласно ПБУ 5/01, фактическая себестоимость запасов, полученных на безвозмездной основе, определялась на основе рыночной стоимости на момент принятия к учету. Теперь, по новым правилам, их фактической себестоимостью признается справедливая стоимость.

10. Запасы, остающиеся после полной ликвидации долгосрочных активов или частичного их выбытия либо полученные в ходе текущего ремонта, содержания, модернизации, реконструкции основных средств, следует оценивать по правилу наименьшей оценки. Необходимо сопоставить две величины, наименьшая из которых будет включаться в фактическую себестоимость запасов:

- стоимость, по которой ведётся учёт аналогичных запасов;

- сумма балансовой стоимости списываемых активов, а также затрат на демонтаж объектов, извлечение материально-вещественных ценностей и приведение их к состоянию, подходящему к дальнейшему применению в качестве запасов [6].

11. Расходы на хранение приобретаемых (создаваемых) запасов со следующего года не будут включаться в их себестоимость. Исключение составляют случаи, при которых хранение является обязательным условием подготовки запасов к следующему этапу производства (например, древесные материалы, приобретающие производственную ценность через определенный промежуток времени) или обуславливается условиями приобретения (создания) запасов. Ранее расходы на хранение, без каких либо исключений, включались в себестоимость.

12. Запасы необходимо будет оценивать как на момент их признания, так и на отчетную дату. Для того чтобы оценить запасы на отчетную дату необходимо рассчитать фактическую себестоимость и чистую стоимость продажи и выбрать наименьшую из двух величин. Однако для организаций, ведущих упрощенный бухгалтерский учет, стандартом предусмотрено право оценивать запасы на отчетную дату по фактической себестоимости.

13. В бухгалтерской (финансовой) отчетности раскрываются сведения о сверке начальных и конечных остатков запасов и их движении за отчетный период. Ранее информация о сверке не раскрывалась.

Также следует отметить, что данный стандарт не применяется бюджетными организациями (для них разрабатываются соответствующие профильные стандарты). Вправе не применять стандарт микропредприятия, однако не все, а только те, которые могут вести упрощенный бухгалтерский учет. Затраты в виде стоимости запасов они отнесут к текущим расходам периода.

Любой организацией может быть принято решение о неприменении стандарта в отношении запасов для управленческих нужд. Выделение этой категории из общей совокупности запасов не является обязательным и носит рекомендательный характер. Но если принято решение обособить запасы для управленческих нужд, то затраты, которые должны были быть включены в стоимость запасов, признаются расходами текущего периода. Указанное решение должно быть раскрыто в бухгалтерской (финансовой) отчетности организации. Перечень таких затрат утверждается организацией самостоятельно локальным документом. В ПБУ 5/01 такие запасы не выделялись из совокупного перечня и учитывались в общем порядке.

Предусмотрены два способа перехода на ФСБУ 5/2019:

- полный ретроспективный подход - наиболее затратный и трудоемкий подход, который потребует корректировки ранее представленной 
информации. Он актуален для крупных организаций, в которых запасы занимают большую долю всех активов.

- модифицированный подход (более подходящий для небольших организаций, в которых доля запасов в активах несущественна), применяемый только в отношении операций, событий, сделок, произошедших начиная с 1 января 2021 г.

Организациям не обязательно применять ретроспективный пересчет данных, сформированных до перехода на новый стандарт. Последствия изменений организация может отобразить перспективно, отражая новые события по новым правилам. Но выбор перспективного или ретроспективного метода должен быть прописан в учетной политике.

Из вышесказанного следует, что изменения, вносимые в правила учета запасов существенно отличаются от прежнего порядка. В связи с этим организации должны учесть эти нововведения в своей работе, а именно: актуализировать положения учетной политики, провести экспертизу локальных нормативных документов на предмет их соответствия требованиям нового стандарта, разработать при необходимости отсутствующие документы, обновить настройки автоматизированной учетной системы и прочее.

Таким образом, применение опыта международной учетной практики обусловлено экономической необходимостью. Кроме того, следует отметить, что с переходом на новые федеральные стандарты существенно снизятся расходы компаний на трансформацию финансовой отчетности (либо необходимость в этом может вообще отпасть), поскольку ФСБУ максимально приближены к МСФО. Поэтому внедрение МСФО в отечественную систему бухгалтерского учета посредством создания ФСБУ и, как следствие, прозрачная и качественная финансовая отчетность, является важным условием развития, как финансового, так и реального сектора экономики в условиях нестабильности. Только эффективное взаимодействие между государством, предприятиями реального сектора экономики и профессиональными сообществами бухгалтеров и аудиторов будет способствовать ускорению процесса внедрения международного опыта и гармонизации учетных систем.

$$
* * *
$$

1. Международный стандарт финансовой отчетности (IAS) 2 "Запасы" (введен в действие на территории Российской Федерации Приказом Минфина России от 28.12.2015 №217н) (в ред. от 11.07.2016) //СПС КонсультантПлюс. - Москва, 2020.

2. Международный стандарт финансовой отчетности (IFRS) 13 «Оценка справедливой стоимости» (введен в действие на территории Российской Феде-рации Приказом Минфина России от 28.12.2015 №217н) (в ред. от 11.07.2016) //СПС КонсультантПлюс. — Москва, 2020.

3. Федеральный стандарт бухгалтерского учета «Запасы» (ФСБУ 5/2019): приказ Минфина РФ от 15.11.2019 г. №180н // СПС КонсультантПлюс. — Москва, 2020.

4. Положение по бухгалтерскому учету «Учет материально-производственных запасов» (ПБУ 5/01): приказ Минфина РФ от 9.06.2001 г. №44н (в ред. от 16.05.2016) // СПС КонсультантПлюс. — Москва, 2020.

5. Положение по бухгалтерскому учету «Учет расходов по займам и кре-дитам» (ПБУ 15/2008): приказ Минфина РФ от 6.10.2008 г. №107н (в ред. от 16.04.2015) // СПС КонсультантПлюс. Москва, 2020.

6. Дружиловская Э.С. Совершенствование правил оценки запасов в бух-галтерском учете современных коммерческих и некоммерческих организаций // Бухгалтерский учет в бюджетных и некоммерческих организациях. —2018. —№23. С. 2-11. 